\title{
IMPROVEMENT OF COAGULATION PROCESS FOR THE PRUT RIVER WATER TREATMENT USING ALUMINUM SULPHATE
}

\author{
Larisa Postolachi*, Vasile Rusu, Tudor Lupascu, Alexei Maftuleac \\ Institute of Chemistry of Academy of Sciences of Moldova, 3 Academiei str., Chisinau, MD-2028, Republic of Moldova \\ *e-mail: larisa.postolachi@gmail.com; phone: (+373 22) 73 97 31; fax: (+373 22) 739954
}

\begin{abstract}
The aim of presented research was to optimize the treatment process of the Prut River water. In order to realize the proposed goal, there were studied the following factors which can improve the process of coagulation: (i) the influence of stirring speed during coagulation and (ii) the influence of the concentration of the coagulant solution added in the process of coagulation. The optimal conditions of coagulation were established using the Jar-test method. Application of the recommended procedure contribute to the reduction of the coagulant dose, the contact time, the aluminum concentration in water and the expenses for water treatment.
\end{abstract}

Keywords: coagulation, aluminum sulphate, Jar-test method.

Received: February 2015/ Revised final: April 2015/ Accepted: April 2015

\section{Introduction}

Natural water is a heterogeneous medium due to the presence of particulate materials and micro-bubbles of gas. The particulate materials of natural waters are distinguished by their size. The particles with sizes of less than $10 \mu$ have a sedimentation velocity less than $0.01 \mathrm{~cm} / \mathrm{s}$, and are evenly distributed throughout the water horizon [1]. With decreasing of particle size, the time required for settling has increased. Due to very small dimensions, the only way to separate the particles is their agglomeration into bigger ones that settles easier. Rejecting electrostatic forces prevent the particles to reach each other, and the suspension is stable [2].

For removal of fine-dispersed and colloidal impurities, the methods of coagulation and flocculation are often applied. Coagulation is based on the interaction of colloid and fine-dispersed particles with aggregates formed upon adding of coagulants. This method was first used at the beginning of XX century [1]. Coagulation can be used both on treatment of drinking water [3-7] and on the purification of waste water [8-10].

The role of coagulation is to overcome the factors that contribute to the stability of the given system. It is achieved using the suitable chemical substance, typically aluminum or iron salts, so-called coagulants. The coagulation process takes place in two distinct steps. The first step is the adding of coagulant; as a result, the destabilization of colloidal suspension occurs and the flocs are formed. During second step, the formation of agglomerates, large agglomerates, takes place, which can easily be separated by gravitational sedimentation [2].

The most widely used coagulant is the aluminum sulphate, which has been used for water treatment [2] applied in a number of countries since the early 1900 [11]. It, usually, is obtained by reaction of bauxite with sulphuric acid [2, 12].

Coagulation is the main reaction stage for the removal of natural organic matter and other contaminants in water treatment processes. The choice of a coagulant has a major influence on the performance of the coagulation process [13]. The aluminum sulphate is used at the purification of water with high turbidity. This coagulant is characterized by relatively low cost, good solubility, no special requirements for the use of dry and dissolved product. It was demonstrated the high efficacy at the removal of humic substances, using the aluminum sulphate [14]. Its application ensures the satisfactory effect in the pollutants removal without adding any additive agents [6].

The beneficial effects of the use of aluminum as a coagulant in water treatment are recognized. However, according to the World Health Organization [15], the excess of aluminum is a risk factor for the development or acceleration of Alzheimer's disease. The contribution of drinking-water to the total oral exposure to aluminum is usually about $5 \%$ of the total intake. Taking this into account, a practicable level is derived, based on optimization of the coagulation process in drinking-water plants, to minimize aluminum levels in water at final stage. Several approaches are available for minimizing residual aluminum concentrations in treated water. These include (i) use of optimum $\mathrm{pH}$ in the coagulation process, avoiding excessive aluminum dosage, (ii) good mixing at the point of application of the coagulant, (iii) optimum paddle speeds for flocculation and (iv) efficient filtration of the aluminum flocs.

The goal of this paper was to perform the coagulation tests, establishing the influence of different factors in the laboratory conditions and at the Water Treatment Plant, Municipal Company "Apa-Canal”, town Ungheni (Republic of Moldova).

\section{Experimental}

The efficiency of the coagulation process depends on raw water quality, the coagulant used and operational factors, including mixing conditions, coagulation dose and $\mathrm{pH}$. The required coagulant dose and $\mathrm{pH}$ can be determined by using small-scale batch coagulation tests, often termed Jar-test (tests with the volume of water of the order of $1 \mathrm{~L}$ 
and above) [15]. Jar test is a pilot-scale test of the treatment chemicals used in a particular water plant. It simulates the coagulation/flocculation process in a water treatment plant and helps operators determine if they are using the right amount of treatment chemicals, and, thus, improves the plant's performance [16].

Increasing doses of coagulant are applied to raw water samples that are stirred and allowed to settle. The optimum dose is selected as that which achieves adequate removal of turbidity; the optimum $\mathrm{pH}$ can be selected in a similar manner. These tests have to be conducted at a sufficient frequency to keep pace with changes in raw water quality and hence coagulant demand [15].

In our research, the optimal conditions of coagulation were established using the Jar-test method [16,17]. During experiment there was used the modelled water (MW, tap water with turbidity modified with aquatic sediments) and the natural water from the Prut River (town Ungheni). The coagulation process was studied using the raw water with turbidity between 33-109 nephelometric turbidity units (NTU). As coagulant, the aluminum sulphate $\left(\mathrm{Al}_{2}\left(\mathrm{SO}_{4}\right)_{3} \cdot 18 \mathrm{H}_{2} \mathrm{O}\right)$ was used, the working solutions being of 1,10 and $25 \%$. The different coagulant doses were studied, i.e. from 3.7 to $35 \mathrm{mg} / \mathrm{L}$.

In the sample of raw water $(800 \mathrm{~mL})$ the required amount of coagulant has been added slowly [18]. Then the sample was subjected to rapid mixing $(500 \mathrm{rpm})$ for 2 minutes, followed by a slow mixing $(120 \mathrm{rpm})$ for 20 minutes. After mixing the samples have been left for sedimentation. At the end of the settling period, the supernatant is withdrawn for analyses. During the Jar-testing the dynamics of turbidity and value of $\mathrm{pH}$ have been determined (Table 1).

Monitored parameters during tests of coagulation.

\begin{tabular}{lcccc}
\hline $\begin{array}{c}\text { Analyzed } \\
\text { parameter }\end{array}$ & Raw water & $\begin{array}{c}\text { Water after 20 minutes } \\
\text { of settling }\end{array}$ & $\begin{array}{c}\text { Water after 40 minutes } \\
\text { of settling }\end{array}$ & $\begin{array}{c}\text { Water after 60 minutes } \\
\text { of settling }\end{array}$ \\
\hline $\mathrm{pH}$ & + & + & + & + \\
Turbidity & + & + & + & + \\
\hline
\end{tabular}

The turbidity has been determined in accordance with standard GOST 3351-74 [19]. The turbidity removal $\left(R_{T}, \%\right)$, which expresses the efficiency of the process, was calculated using the following Eq.(1) [20]:

$R_{T}=\frac{T_{i}-T}{T_{i}} \cdot 100 \%$,

where: $T_{i}$ - initial turbidity, NTU;

$T$ - residual turbidity, NTU.

In order to optimize the process of coagulation there were studied the following factors: (i) the influence of mixing speed and (ii) the influence of the concentration of coagulant added in the process of coagulation.

This paper presents a study regarding the water treatment with aluminum sulphate, aiming to obtain drinking water with turbidity values lees than 5 NTU, according the existing criteria. The existing drinking water criteria for studied parameters are presented in Table 2.

Table 2

The limit values of studied parameters according to different criteria for drinking water.

\begin{tabular}{lccc}
\hline \multicolumn{1}{c}{ Parameter } & $\begin{array}{c}\text { Directive 98/83/EC } \\
\text { (European Union) [21] }\end{array}$ & $\begin{array}{c}\text { Law 458/2002 } \\
\text { (Romania) [22] }\end{array}$ & $\begin{array}{c}\text { Order 934/2007 } \\
\text { (Republic of Moldova) [23] }\end{array}$ \\
\hline $\mathrm{pH}$ & $6.5-9.5$ & $6.5-9.5$ & $6.5-9.5$ \\
Turbidity & $\leq 1 \mathrm{NTU}$ & $\leq 5 \mathrm{NTU}$ & $\leq 5 \mathrm{NTU}$ \\
\hline
\end{tabular}

\section{Results and discussion}

\section{The main stages applied in the potabilization technologies of natural waters}

The water quality from surface sources (rivers, lakes) often does not correspond to the drinking water criteria, because of the high turbidity, the high content bacteria or dangerous dissolved substances. In order to be consumed, the natural water would be processed, so as to meet the existing criteria for drinking water.

The role of treatment plant is to "correct" the raw water quality to achieve user requirements [24]. The main stages applied in the potabilization technologies of natural waters are presented in Figure 1 and include the following:

- pre-oxidation is the permanent process that should ensure the optimal operation of subsequent processes, removing the organic matter presented in water, the analyzed parameters being the biochemical oxygen demand;

- the process of water clearness consisting of coagulation and flocculation processes - in order to obtain a performance at this stage the choice of coagulant is essential, the analyzed parameters being turbidity and $\mathrm{pH}$ value;

- decantation for retain the coagulated suspensions (flocs); 
- filtration for finishing of the clearness process;

- water conditioning which consists of oxidation with ozone, followed by adsorption on granular activated carbon in order to remove the toxic chemical compounds;

- water disinfection for the total removal of viruses, bacteria and other micro-organisms from the water.

For the coagulation of particulate materials, the aluminum sulphate is the most commonly used, which by hydrolysis and the formation of oligomers with complex structures into a wide range with high loads (from $\left[\mathrm{Al}_{2}(\mathrm{OH})_{2}\left(\mathrm{H}_{2} \mathrm{O}\right)_{8}\right]^{4+}$ to $\left.\left[\mathrm{Al}_{28}(\mathrm{OH})_{70}\left(\mathrm{H}_{2} \mathrm{O}\right)_{28}\right]^{14+}\right)$ facilitates the aggregation and sedimentation of particulate materials from water [25].

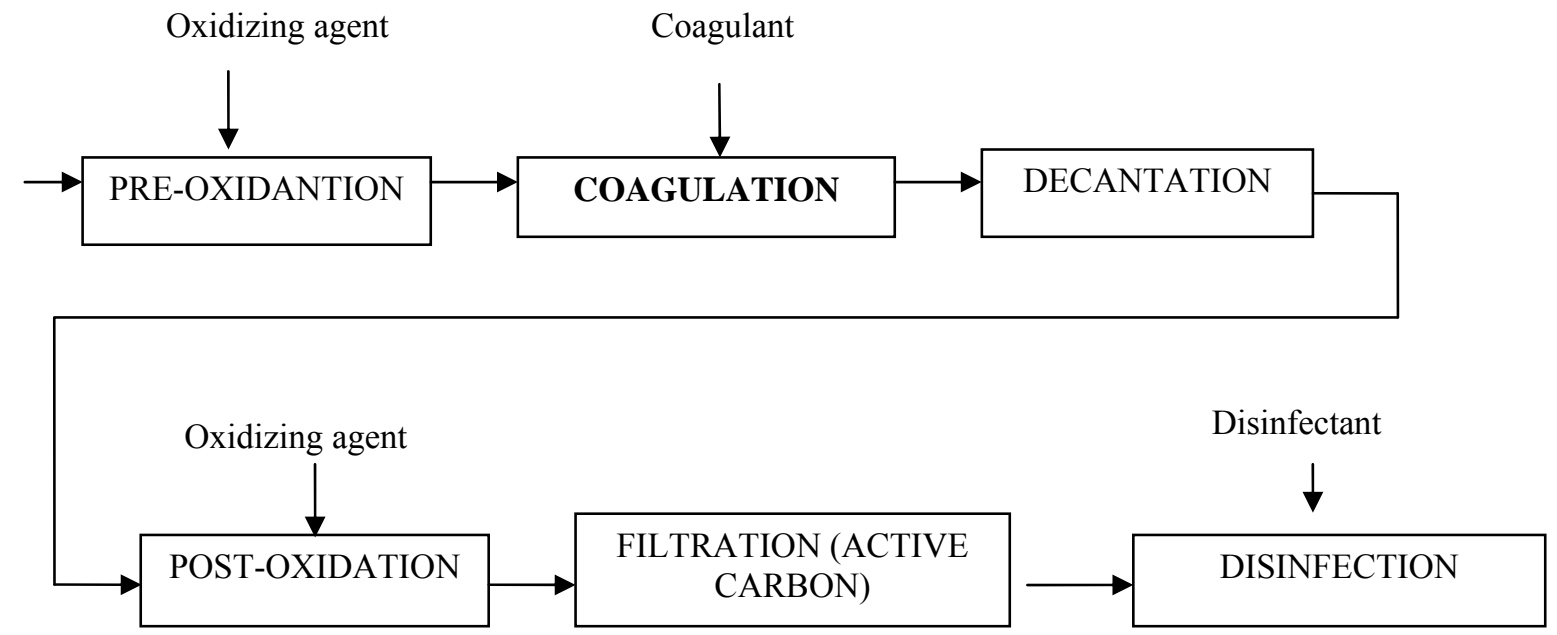

Figure 1. The main steps of potabilization technologies applied for natural waters [24].

\section{Jar-testing performed on $M W$}

The turbidity removal during the coagulation process depends on the colloids type, temperature, the $\mathrm{pH}$ value and chemical composition of the water, the type and dosage of coagulant, and the contact time provided for the formation of agglomerates [26].

Numerous Jar-tests were carried out in order to establish a practical understanding of the coagulation performance for this application. Initially, the coagulation process was studied on MW with turbidity between 33 and 40 NTU (Figures 2 and 3).

Experiments were carried out to determine the optimum dose of aluminum sulphate. During Jar-testing it was founded that during rapid mixing (Figure 2) the coagulation process was less efficient in comparison with the results obtained in conditions of the regular mixing (Figure 3). It was also established that in the conditions of the regular mixing at doses of coagulant in the range from 3.7 to $9.8 \mathrm{mg} / \mathrm{L}$ the turbidity of water falls below $5 \mathrm{NTU}$.



Figure 2. Residual turbidity for MW as function of coagulant dose, in conditions of rapid mixing (coagulant concentration of $1 \%$ ). $\mathbf{P}$ - probability level. 


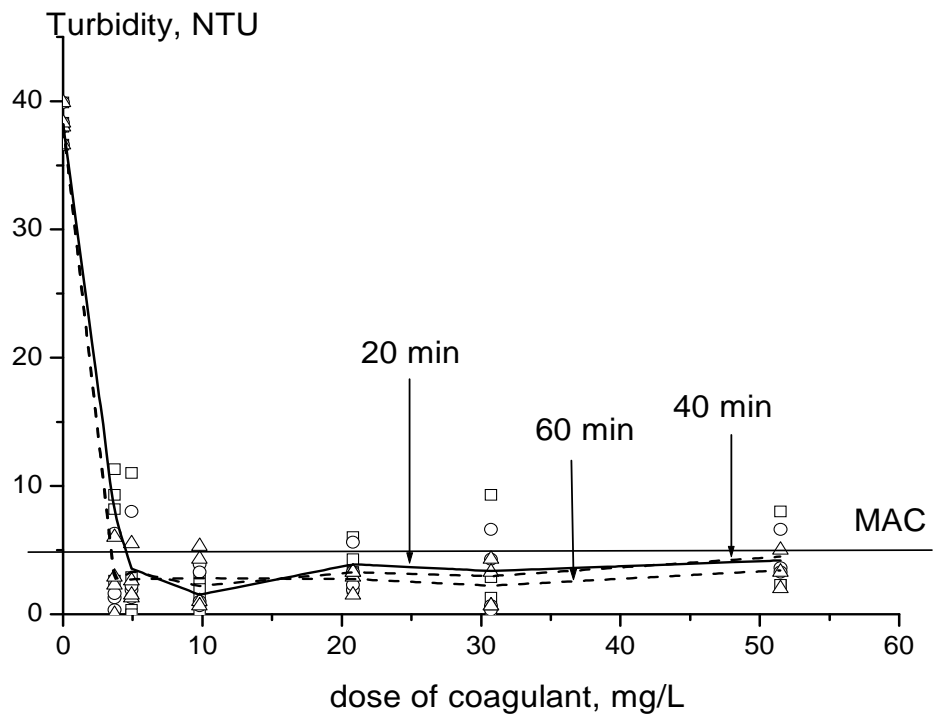

Figure 3. Residual turbidity for MW as function of coagulant dose, in conditions of regular mixing (coagulant concentration of $\mathbf{1 \%}$ ). MAC - maximal admissible concentration.

The concentration of the coagulant solution is an important factor in the coagulation process [18]. In this paper there has been studied the effectiveness of different dosages of the coagulant during the coagulation process in MW, being used the aluminum sulphate solution at various concentrations (10 and 25\%) (Figures 4 and 5). The highest values of turbidity removal (83-93\%) were obtained using more concentrated solution of the coagulant $(25 \%)$.

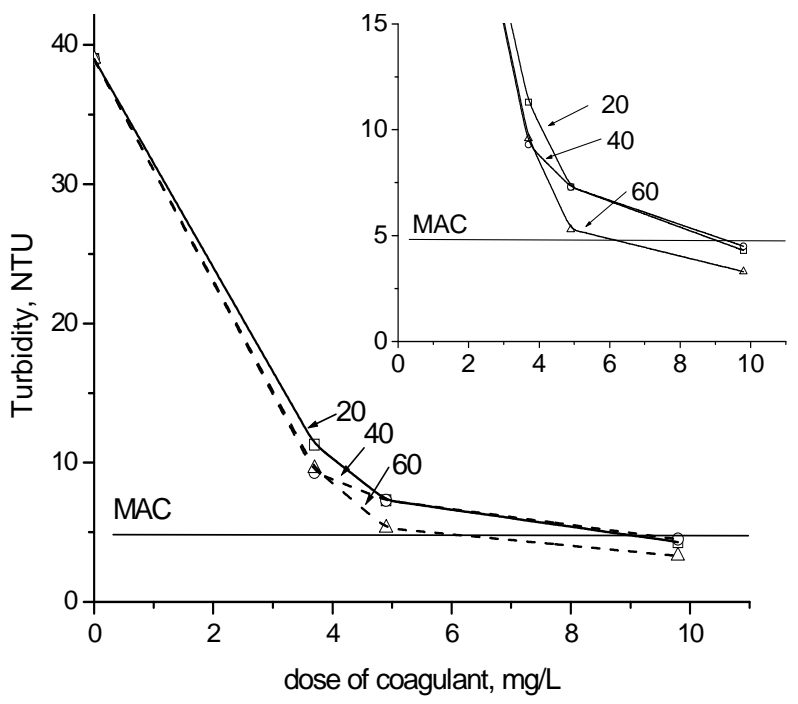

Figure 4. Residual turbidity for MW as function of coagulant dose (coagulant concentration of $10 \%$ ) for different settling time (20, 40, and 60 minutes).

During the coagulation process, at the adding of coagulant the $\mathrm{pH}$ value of water has decreased [18]. Depending on the dose of coagulant (Figure 6), the $\mathrm{pH}$ value in water has decreased up to 7.5, which framing in limits of the accepted standards (Experimental, Table 2). 

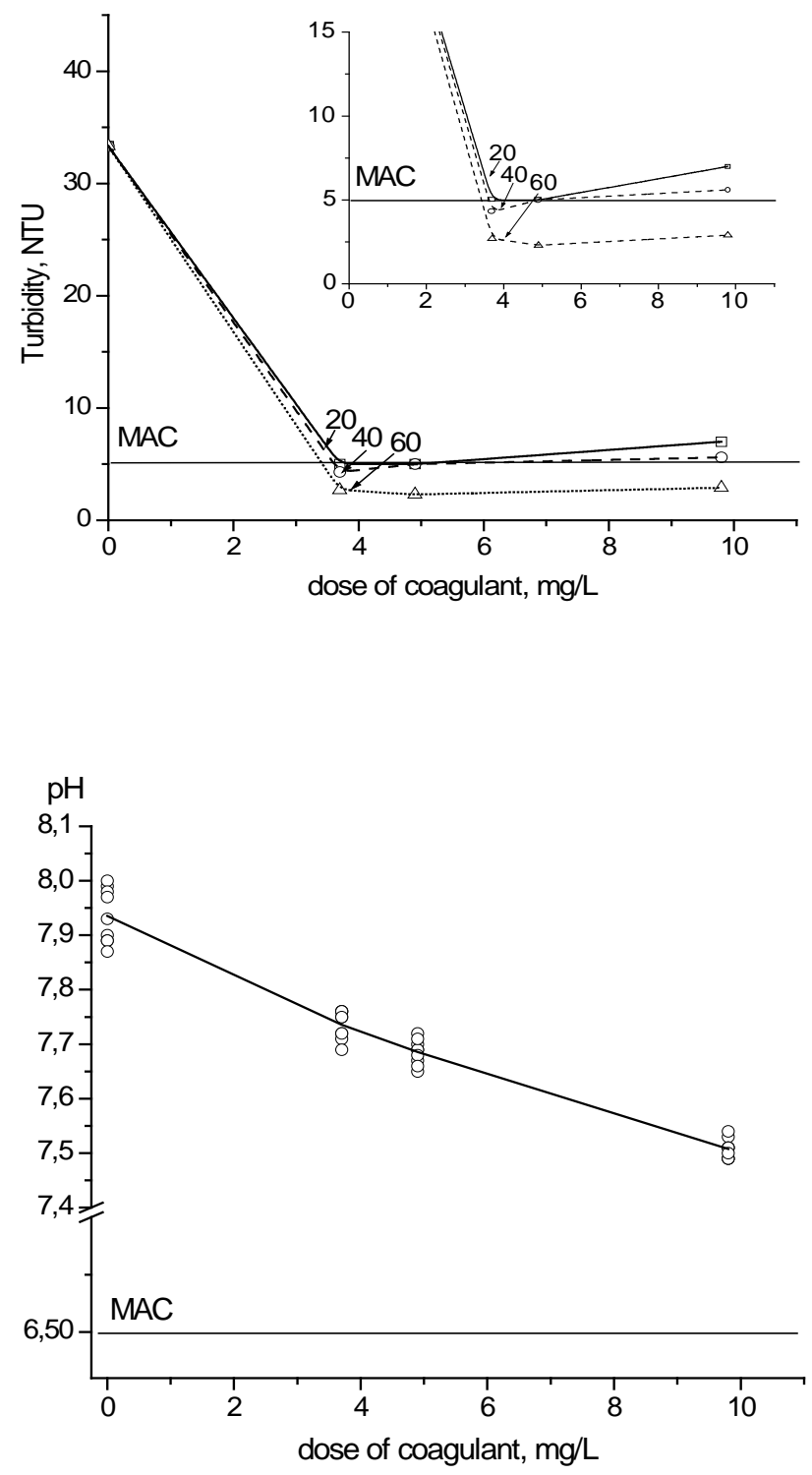

Figure 5. Residual turbidity for MW as function of coagulant dose (coagulant concentration of $25 \%$ ) for different settling time (20, 40, and 60 minutes).

\author{
Figure 6. The variation of $\mathrm{pH}$ \\ value in MW as function of added \\ coagulant dose.
}

\section{Jar-testing performed on natural water}

The role of the coagulant agent depends on many factors including speciation of the hydrolysis products, quantity and reactivity of complexing ligands, and the rate of mass transfer between these components. The $\mathrm{pH}$ value of raw water is an important factor in determining the physical and chemical properties of the water as well as the hydrolyzates or the stability of coagulants. The efficiency of the $\mathrm{pH}$ is relative with the molecular structure of coagulants. The aluminum sulphate would generate various hydrolyzates such as $\left[\mathrm{Al}_{2}(\mathrm{OH})_{2}\right]^{4+},\left[\mathrm{Al}_{3}(\mathrm{OH})_{4}\right]^{5+}, \mathrm{Al}(\mathrm{OH})_{3}$, and $\mathrm{Al}(\mathrm{OH})_{4}^{-}$ corresponding to different $\mathrm{pH}$ values of water. Those different hydrolyzates would exert a different effect on colloidal particles so that the mechanism and efficiency of the coagulation would be changed. When the solution $\mathrm{pH}$ is lower than 6 , the positive hydrolyzates such as $\left[\mathrm{Al}_{2}(\mathrm{OH})_{2}\right]^{4+}$ and $\left[\mathrm{Al}_{3}(\mathrm{OH})_{4}\right]^{5+}$ could easily neutralize the colloidal particles with negative charges and further destabilize the colloids. Those positive hydrolyzates also generated the physical and/or chemical adsorption of the destabilized colloids [13].

In order to establish the optimal conditions of coagulation, the tests of coagulation on the raw water of the Prut River at the Water Treatment Plant of Municipal Water Company, Ungheni were carried out. As a coagulant the aluminum sulphate is used at Water Treatment Plant. The turbidity of natural water during the research period was in the range 50-109 NTU. The dose of coagulant was varied from 3.7 to $35 \mathrm{mg} / \mathrm{L}$.

During of coagulation tests conducted on raw water at doses of coagulant in the range $3.7-9.8 \mathrm{mg} / \mathrm{L}$, the turbidity have been decreased below value of 5 NTU (Figures 7-9).

Studying the efficiency of different doses of coagulant in coagulation process, the coagulant concentrations of 10 and $25 \%$ have been used (Figures 8 and 9 ). During the coagulation tests, the maximal values of the turbidity removal $(89-98 \%)$ were obtained using more concentrated solution of coagulant $(25 \%)$. 

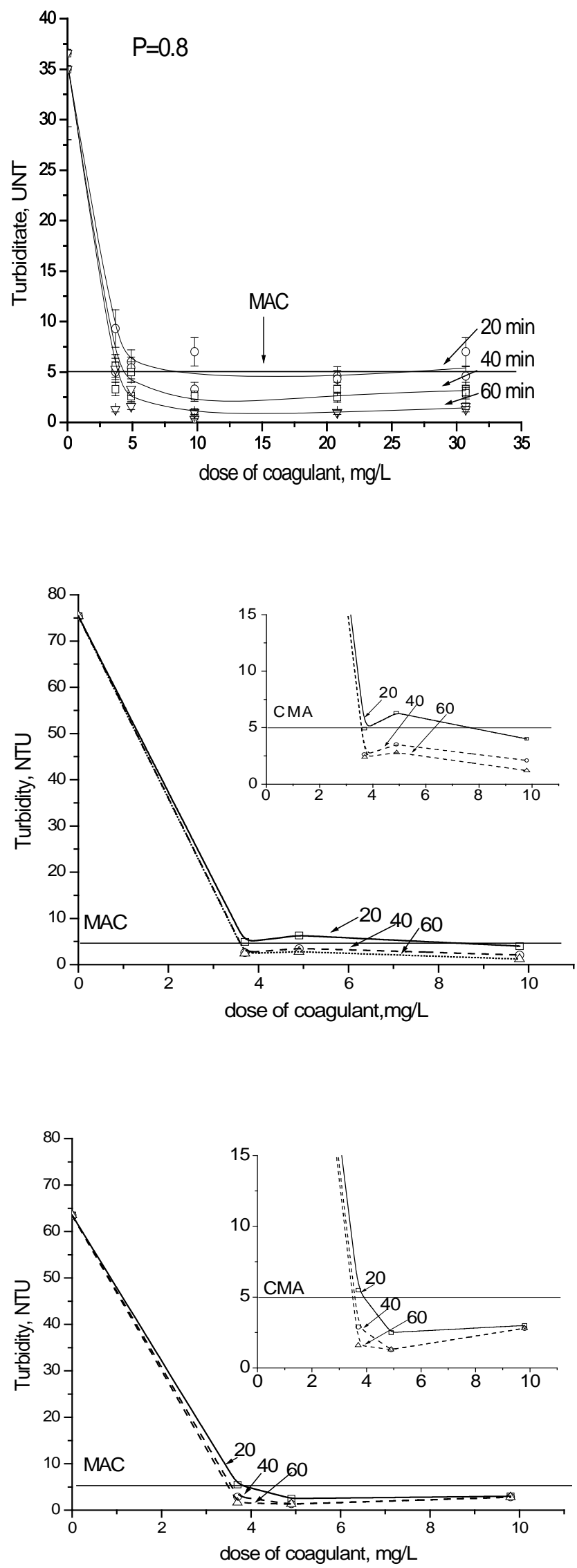

Figure 7. Residual turbidity for raw water, as function of coagulant dose (coagulant concentration of $1 \%$ ).

$\mathbf{P}$ - probability level.

MAC - maximal admissible concentration.
Figure 8. Residual turbidity for raw water as function of coagulant dose (coagulant concentration of $\mathbf{1 0} \%$ ) for different settling time (20, 40, and 60 minutes).
Figure 9. Residual turbidity for raw water as function of coagulant dose (coagulant concentration of 25\%) for different settling time (20, 40, and 60 minutes). 
During the Jar-testing, the $\mathrm{pH}$ value of raw water decreased (Figures 10 and 11). Depending of the coagulant dose, the $\mathrm{pH}$ value have been decreased until 7.2; value that didn't exceed the established standards (Table 2).
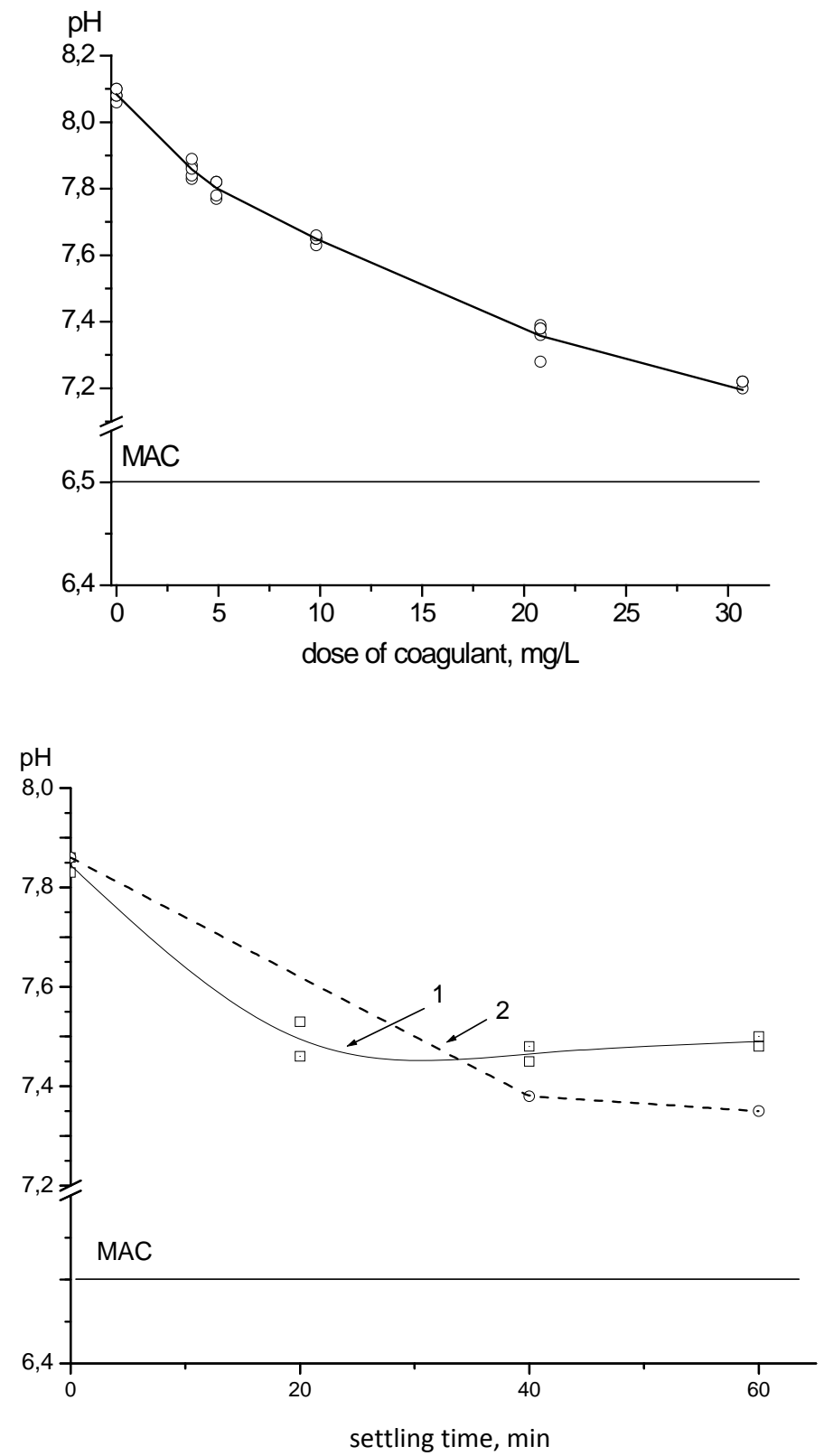

Figure 10. The variation of $\mathrm{pH}$ value in raw water, as function of added coagulant dose.

MAC - maximal admissible concentration.
Figure 11. The variation of $\mathrm{pH}$ value in raw water, as function of added coagulant dose

(1 - $4.9 \mathrm{mg} / \mathrm{L}, 2$ - $9.8 \mathrm{mg} / \mathrm{L}$ ).

MAC - maximal admissible concentration.

\section{Conclusions}

Based on laboratory studies at the Water Treatment Plant, Municipal Enterprise, Ungheni, it was established that in conditions of regular mixing (rapid stirring for 2 minutes, followed by slow stirring for 20 minutes) the optimal dose of coagulant could be reduced to approximately $10 \mathrm{mg} / \mathrm{L}$, being registered the decreasing of the turbidity value less than 5 NTU. The residual $\mathrm{pH}$ value is framing in limits of the accepted standards.

It was established that the use of concentrated solutions of the coagulant improves the coagulation process, the optimum concentration of aluminum sulphate being of $25 \%$.

Application of the recommended procedure contribute to the reduction of the coagulant dose, the contact time, the aluminum concentration in water and the expenses for water treatment.

\section{Acknowledgments}

Thanks to Ms. Natalia Bors, deputy-director of the Municipal Water Treatment Company "Apa-Canal” of town Ungheni, for her kind support in achievement of this study. 


\section{References}

1. Duca, Gh.; Scurlatov, Y.; Misiti. A.; Macoveanu, M.; Surpateanu, M. Ecological chemistry. Matrix Rom: Bucuresti, 1999, 305 p. (in Romanian).

2. Tzoupanos, N.; Zouboulis, A. Coagulation-flocculation processes in water/wastewater treatment: the application of new generation of chemical reagents. Heat Transfer, Thermal Engineering and Environment (HTE'08). Rhodes, Greece, 2008, pp. 309-317.

3. Grisin, B.; Bikunova, M.; Titov, E. et al. Experimental studies of water purification from Sura reservoir using aluminum-coagulants. Water treatment, 2010, 7, pp. 23-29 (in Russian).

4. Vlaicu, I.; Radovan, C. Application of several aluminum prehydrolysed coagulants to a surface water treatment for potable use. Environmental Engineering and Management Journal, 2009, 8(6), pp. 1371-1376.

5. Meghzili, B.; Medjram, M.; Zoubida, M. Tests of Coagulation - Flocculation by Aluminum Sulphate and Polycations Al13 on Raw Waters of the Station of Treatment Skikda (Algeria). European Journal of Scientific Research, 2008, 23(2), pp. 268-277.

6. Wira, D.; Wira J. Influence of flocculating agents onto the water coagulation course. Baltic Coastal Zone, 2006, 10, pp. 147-166.

7. Zamfiroiu, E.; Masu, S. Aspects Regarding the Efficiency of Coagulation Process for Some Surface Waters. Chemical Bulletin of Polytechnic University of Timisoara, 2007, 52(66), pp. 1-2.

8. Aygun, A.; Yilmaz, T. Improvement of Coagulation-Flocculation Process for Treatment of Detergent Wastewaters Using Coagulant Aids. International Journal of Chemical and Environmental Engineering, 2010, 1(2), pp. 97-101.

9. Klimiuk, E.; Filipkowska, U.; Libecki, B. Coagulation of Wastewater Containing Reactive Dyes with the Use of Polyaluminum Chloride (PAC). Polish Journal of Environmental Studies, 1999, 8(2), pp. 81-88.

10. Zaleschi, L.; Teodosiu, C.; Cretescu, I.; Rodrigo, M. A comparative study between electrocoagulation and chemical coagulation applied for wastewater treatment. Environmental Engineering and Management. Book of abstracts, Bahatonalmadi, Hungary, 2011, pp. 123-124.

11. Jalba, K.; Bucur, A. Residual aluminum — quality criteria for drinking water. Hydrotechnics, 1987, 32(4), pp. 14 19 (in Romanian).

12. Manual for testing of water and wastewater treatment chemicals (Final Report), Water Research Commission, http://www.wrc.org.za/Knowledge\%20Hub\%20Documents/Research\%20Reports/1184\%20web.pdf.

13. Zhang, Z.; Wu, C.; Wu, Y.; Hu, C. Comparison of coagulation performance and floc properties of a novel zirconiumglycine complex coagulant with traditional coagulants. Environmental Science and Pollution Research, 2014, 21, pp. 6632-6639.

14. Babenkov, E. Water treatment using the coagulants. Nauka: Moskva, 1977, 356 p. (in Russian).

15. Guidelines for Drinking-water Quality. World Health Organization: Geneva, 4th Edition, 2011, $541 \mathrm{p}$.

16. Satterfield, Z. Jar Testing. Technical Brief, 2005, 5(1), pp. 1-4.

17. Pask, D. Jar Testing: Getting started on a low budget. On Tap, 1993, 2(2), pp. 4-6.

18. Stumm, W.; Morgan, J. Chemical aspects of coagulation. Journal of the American Water Works Association, 1962, 54, pp. 971-992.

19. GOST 3351-74 Drinking water. Methods for determination of turbidity. Gosstandart Rossii: Moskva, 1992 (in Russian).

20. Stefan, D.; Costache, C.; Ruxandu, V.; Balas, M.; Stefan, M. Comparative study on surface water treatment using aluminum sulphate and polyaluminum chlorides as coagulant reagents. Environmental Engineering and Management Journal, 2009, 8(4), pp. 859-863.

21. EC Directive, Directive 98/83/EC of the European Parliament and of the Council of 3 November 1998, on the quality of water intended for human consumption. Official Journal of the European Communities, L 330/32, 5.12.1998, Brussels.

22. Law no. 458/2002 of 07 August 2002 on drinking water quality. Official Journal of Romania, Part I, 29.07.2002, no. 552 (in Romanian).

23. Governmental Decision no. 934 of 15 August 2007 regarding the establishment of automated information system "State Register of natural mineral and drinking waters and soft bottled drinks". Official Journal of the Republic of Moldova, 24.08.2007, no. 131-135 (970) (in Romanian).

24. Toma, P. Considerations regarding the operation of water treatment plants. Journal of Environmental Research and Protection, 2012, 32, pp. 27-34 (in Romanian).

25. Rusu, V.; Lupascu, T. Chemistry of aquatic sediments. Properties of surface. Physicochemical models. Elena V.I.: Chisinau, 2004, 272 p. (in Romanian).

26. Cical, E.; Burtica, G.; Gasparik, G.; Negrea, A.; Lupa L. Contributions regarding the combined use of the coagulation reagents. Environmental Engineering and Management Journal, 2006, 5(6), pp. 1263-1266. 